\title{
How Effective is the Diocesan Educational Leadership in Enhancing a Denominational Education Philosophy in Uganda? Reflections from Roman Catholic Schools in Greater Kampala (Uganda)
}

\author{
Anthony Mugagga Muwagga ${ }^{1}$, Gyaviira Musoke Genza ${ }^{1, *}$, Rex Regis Ssemulya ${ }^{2}$ \\ ${ }^{1}$ School of Education, College of Education \& External Studies, Makerere University, Uganda \\ ${ }^{2}$ Uganda Martyrs Secondary School, Namugongo, Wakiso, Uganda \\ *Corresponding author: musokegenza@gmail.com
}

\begin{abstract}
This study investigated the effectiveness of the Diocesan educational leadership in enhancing a denominational education philosophy in view of learners' holistic growth and development. It took a case study of Catholic schools in the Greater Kampala District of Uganda. The study discovered that although in principle the Catholic Church highly espouses its denominational education philosophy, the practice is different. In this, the Church is especially betrayed by an apparent ineffectiveness of its Diocesan educational leadership in supervising its schools. Implications for both denominationalism and nationals' integral growth and development are discussed.
\end{abstract}

Keywords: denominational philosophy of education, educational leadership, school supervision

Cite This Article: Anthony Mugagga Muwagga, Gyaviira Musoke Genza, and Rex Regis Ssemulya, "How Effective is the Diocesan Educational Leadership in Enhancing a Denominational Education Philosophy in Uganda? Reflections from Roman Catholic Schools in Greater Kampala (Uganda)." American Journal of Educational Research, vol. 6, no. 1 (2018): 88-95. doi: 10.12691/education-6-1-14.

"A Catholic school is in big trouble when folks can detect no discernable gospel bias in the education it offers" [1]

\section{Introduction: What is at stake?}

There is an ongoing debate in Uganda's educational circles that due to marketplace pressures, denominational schools - those founded by Anglicans, Catholics and Moslems - have deviated away from their original aim of developing the whole person in each of the three domains - body, soul and mind [2]. According to analysts, this deviation has not spared schools of Catholic foundation $[3,4]$. Though ranked as the best academic institutions in Uganda - in terms of their mission and character Catholic founded schools are also reported to have drifted away from their original holistic development approach [5] to adoption of "commercial" practices, just like any Private-For-Profit Secondary/Primary School [3,6].

Different studies opine that Roman Catholic schools have also been secularized in as far as the values they actually espouse are concerned [7,8,9]. For example, they are reported to encourage student private coaching at extra pay, and to teach/work even on days of rest such as Sundays. Related practices alluding to a drift away from the original Catholic philosophy of education include, among others;

- Catholic school head teachers engaging in examination malpractices to create superficial pupil/student performance in national examinations. Head teachers "selling off" students they suspect will not perform well in national examinations to other schools. This is done to create an impression that their Catholic schools are able to teach and have all their students achieve a first grade [10].

- Head teachers in both privately-aided and Government-aided Catholic schools running them in isolation of the Diocesan and Local/Parish education Catholic communities [8].

- It is also alleged that some of those Catholic schools headed by the religious (Priests, Brothers and Sisters) are also no exception to secular tendencies like hiring their own (less qualified) kinsmen and over espousing academic grades at the expense of students' moral character development through prayer, sports and charity engagements, among others.

That is what is at stake; and one wonders what the Diocesan educational leadership (such as Education Secretariat and Parish Priests) is/are doing in enhancing a Catholic denominational education philosophy. Might they perhaps be too busy with other concerns at the expense of realities in their schools? Where are members of school's governing and mangement board/commitees in all this? Are they aware of the original mandate of Catholic education? Have secular marked forces perhaps succeeded in derailing also denominational schools from their true course? This study therefore set out to examine the effectiveness of the Diocesan education leadership in 
enhancing a denominational educational philosophy in Uganda, taking Roman Catholic schools as the case of study.

More specifically, the study had two objectives: First, to underline the role of Diocesan educational leadership in enhancing a Catholic denominational education philosophy in principle (literature review); Second, to establish the role that the Diocesan educational leadership is actually playing in enhancing a Catholic denominational education philosophy (survey research).

\section{Denominational Philosophy of Education in the Context of the Catholic Education}

Philosophy has many but closely related meanings and definitions [11]. This paper takes philosophy to mean the intellectual discipline that critically examines peoples' fundamental beliefs about life in general and human existence in particular. Philosophy of education will therefore here imply those implicit and explicit fundamental beliefs which act as the pivot for the inputs and outputs of a particular education system [12]. The beliefs act as spices that season both the official (written) and hidden (invisible) curriculum of a given school. Every established religious denomination has its philosophy of education that spells out its view of a school, the educational process, the educand (learner) and the teacher [11]. "Denominational philosophy of education" may for example be Islamic, Anglican or Roman Catholic, among others. This study focuses on Catholic philosophy of education.

Although Catholic educational philosophy cannot easily be defined using specific terms, its core elements can be discerned from the Church's mission, traditions, social teachings on education, papal writings and even the Bible $[13,14,15]$. For example [7] traces Catholic educational philosophy to Jesus Christ's command to his Apostles: "Go, teach, and make disciples of all nations" (Matthew 28: 18-26). The fundamental purpose of Catholic education and the implied philosophy therefore seems to be to articulate the Christian message and its inherent values and beliefs, to cherish, keep and transmit the culture of the sacred to those in the Church's educational institution [3].

Catholic educational philosophy is therefore not an academic invention of our time. Its documented evidence originates from the times of St. Augustine of Hippo (354-430), through St. Thomas Aquinas (1225-1274) to the Renaissance (Russell, 1996). Contemporary Roman Catholic philosophy of education is also often referred to as "neo-Thomism" or "neo-Scholastic philosophy". This is so because it is a revival of medieval scholasticism in Roman Catholic theology and philosophy [16,17].

Nevertheless, today's Roman Catholic education owes its formal inception to St. Ignatius of Loyola (1491-1556), the founder of the Society of Jesus ("Jesuits"). Ignatius was previously a soldier. When he converted and became a priest he took it upon his followers to defend the Church at all costs, and he saw no better means than through the education of the young. As a result the Jesuits gave
Catholic education a more focused direction and character, namely:

i) The total formation of each individual within his/her human community. This implies that education has to be conducted within and for the community in which the child comes from or will stay in the future [15].

ii) The religious dimension of education permeating all pedagogical activities in the school and entire life of the learner.

iii) Accentuation of the imperative of dialogue between faith and culture, faith (fides) and reason/science (ratio), and individual care and concern for each student [14].

iv) Catholic education as a value and belief oriented education, implying establishment of clear means and practices to transmit a certain set of values critical to the Catholic fraternity, such as: Centrality of Christ as the model for human life (imitation of Christ); centrality of the Eucharist, the Blessed Virgin Mary and the Bible in salvation history; and observance of the Decalogue (ten commandments) as an imperative for all - both in their private and public lives [18].

The Catholic Church's denominational philosophy of education therefore takes a pastoral/evangelising tone. It pivots around the centrality of the human being in the epistemological debate; the development of the body, mind and soul in education; the existence of an infinite and indefinable being called God [13]. The educational component of this philosophy alludes to humanizing the learner through moral and physical education, critical thinking and spiritual formation through regular prayer and worship [16].

The Church's decree on Christian Education ([19]: 726) explains this Catholic educational philosophy more clearly by stating that;

For her part Holy Mother Church, in order to fulfill the mandate she received from her divine founder to announce the mystery of salvation to all men [sic] and to renew all things in Christ, is under obligation to promote the welfare of the whole life of man [sic], including his life in this world insofar as it is related to his heavenly vocation; she has therefore a part to play in the development and extension of education to all persons within its jurisdiction.

Elsewhere, the same decree further notes that;

All men [sic] of whatever race, condition or age, in virtue of their dignity as human persons have an inalienable right to education. This education should be suitable to the particular destiny of the individuals adapted to their ability, sex and national cultural traditions and should be conducive to fraternal relations... True education is directed towards the formation of the human person in view of his final end and the good of that society to which he belongs and in the duties of which he will, as an adult, have a share ([19]: 643).

The decree further underscores the following principles as the fulcrum for all Catholic education [19]:

- School as a special tool for evangelization of peoples. 
- The role of education in nurturing the intellectual faculties of the learner in order to develop a capacity for sound judgment.

- The contribution of education in introducing the learner to Catholic culture and tradition.

- Parents as the key and first teachers for any child. They play a pivotal role in the sane upbringing of their children.

- The centrality of exemplary teachers in both epistemological midwifery and evangelization of learners. Teachers who work in schools of Catholic foundation therefore ought to be well prepared for their dual pedagogy of mediating both corporeal and celestial truths.

Thus, it may be said that Catholic schools, defined as educational institutions founded by the Roman Catholic Church or its associates such as the different Religious Congregations (Canon 803, §1), are no common schools. Rather, they are unique places and spaces in which the young are exposed to the values of the Church. Their uniqueness is for example indicated by their missions and mottos, which allude to learners' divine destiny. For example: "Teach as Jesus taught"; "The love of Christ has gathered us together"; and, "We are one in Christ". Many of the schools founded by the Mill hill, Franciscan Sisters, White Fathers and Brothers of Christian Instruction in Uganda have these mottos clearly printed on their stationery, uniforms and/or sign posts.

This is not to say that Catholic education is just after conversion to Christ. On the contrary, it is clearly positioned to prepare learners for active participation in both the Church and the State [13] through service to their local community $[3,15]$. Learners are prepared early in life for diverse callings such as married life, religious life, or another life, which does not contravene the teaching of Jesus.

In a word, the original and often forgotten aim of Catholic education, and its implied philosophy of education, is to counter any other philosophical stance which is not subservient to genuine Christianity [15]. The Church has never stopped being wary of the spread of secularism and ethical relativism [20]. The Church knows that since its ordained ministers cannot reach "all ends of the earth", its "auxiliaries" (such as head teachers, classroom teachers and management committees) can lend a hand in this apostolic mission [13].

\section{Macro \& Micro Aims of Roman Catholic Founded Schools}

According to $[13,19,21,22]$, Catholic schools are established for a number of aims, some of which are generic (macro) and others are specific (micro) to an individual Ecclesial community's local settings. As macro sub-structures, Catholic schools propagate faith based on the dictates of the Holy See (the Vatican); but at the same time they are micro or local Church projects, which foster the gospel in lieu of the needs of the immediate Diocesan community.

At the macro (generic) level, universal Catholic education aims at; i) Providing space in which the Gospel can fruitfully germinate, following the example cited by Christ in the parable of the farmer scattering seeds: "Still other seeds fell on fertile soil, and they produced a crop that was thirty, sixty, and even a hundred times as much as had been planted." (Matthew 13:8).

ii) Cultivating of persons who in their habits hold a firm disposition to do good; that is, persons who are virtuous - those that typify the Cardinal virtues if prudence, justice, fortitude and temperance.

iii) Creating an atmosphere of growth and development in genuine freedom and charity, where youngsters learn to exercise their freedom informed by the Gospel, living as each other's brother's/sister's keeper. Charitable living is critical of today's world characterised by selfishness and "Am I my brother's keeper?" attitudes.

iv) Illuminating ordinary knowledge with the knowledge of faith ("faith and reason"). A mature Christian is capable of using his/her scientific knowledge not only for mundane ends, but also for his/her final self-realization in God.

v) Outwitting any emerging anti-Christ ideologies those divergent to the Gospel. For example nurturing prolife and pro-environment activists to counter profane scientists who destroy the natural environment [23].

Nevertheless, there are also micro (local) aims of Catholic education, whereby social institutions such as schools are meant to be arenas where responsible citizens are nurtured for the local Church [24,25]). Ipso facto, a good Christian is expected to be a good citizen. Therefore Catholic schools also aim at;

a) Nurturing men and women who in future will form good Christian families, good politicians, civil servants, religious men and women, and all other professionals, are nurtured.

b) Providing indigenous role models to learners. In these schools, staff are the salt of the earth and light of the world (Mt. 5:13). It is at school that the moral game is expected to be practically learnt, hence becoming the norm of the day $[25,26]$.

c) Supporting other local pastoral programs, depending on each school's resources.

Globally, "the Catholic Church runs 73,263 kindergartens with 6,963,669 pupils; 96,822 primary schools with $32,254,204$ pupils; 45,699 secondary schools with 19,407,417 pupils. The Church also cares for $2,309,797$ high school pupils, and 2,727,940 university students" [27]. These statistics imply that the Catholic Church is a significant stakeholder in the education of the young in almost all parts of the world. Its impact to almost all nations through its routine contacts with such a multitudes of pupils and students in school can be immense.

However - the ideal situation apart - how effective is the local Diocesan educational leadership in enhancing such a denominational philosophy? What do reports and practices on the ground seem to suggest? The next section attempts to answer such questions by reporting on a survey of Catholic founded schools in Uganda. However, the section opens with a contextualisation of Catholic education in Uganda. 


\section{Historical Context of Roman Catholic Education in Uganda}

In Uganda, formal education was started in 1877 and 1879 by Anglican and Roman Catholic missionaries, respectively [28]. The British colonial government left formal education to these (and other) missionaries, until more than 30 years later. On their part, missionaries used education as a tool not only for evangelization but also as an anchor for social change in the country. Today the Catholic Church runs three categories of schools, namely:

i) Secular Roman Catholic founded schools. These are either privately or government aided Catholic founded schools, but always affiliated to a Catholic Diocese. They are the majority - whether preprimary, primary, secondary or tertiary education institutions.

ii) Religious formation educational institutions. These are either congregational or diocesan seminaries (or novitiates) set up and working within the jurisdiction of a particular Bishop or the Uganda Catholic Secretariat.

iii) Catechetical centres: Diocesan institutions, which train local catechists or lay evangelisers.

This paper focuses on category one - the secular Catholic founded schools - excluding specialized religious schools, novitiates and catechetical centres, given their more complex and, sometimes, secluded setup.

Most of the secular Roman Catholic founded schools established by missionaries are still ranked as the top schools in the country. Examples are Mt. St Mary's College Namagunga (a girls school established in 1942 by the Franciscan Missionary Sisters); Mt. St. Mary's Kisubi (established by the Brothers of Christian Instruction in 1906); Namilyango College (established in 1902 by the Mill hill Missionaries); and St. Henry's College Kitovu (established in 1922). There are also those founded after independence, such as Uganda Martyrs Secondary School Namugongo (established in 1967 by the local Catholic Christian community).

\section{Management Context of Catholic Founded Schools in Uganda}

Within the Roman Catholic jurisdiction, schools are micro units but within a macro Church setup. The Bishop of Rome is the titular head of them all; however, he is represented by a given Bishop in each local territory known as a Diocese. In the Ugandan context, the following pyramidal structure applies $[3,8,24]$ :

i) Diocesan Bishop: Tasked with the responsibility of looking after all Roman Catholic founded (and affiliate) educational institutions, by virtue of his pastoral role [19].

ii) Diocesan Education Secretary (DES): Appointed by the Bishop to preside over all Diocesan schools as his CEO (Chief Executive Officer).

iii) Parish Priest and the Father-in-charge-of-Schools or Chaplain: These directly work with the DES (Diocesan Education Secretary) to execute educational roles and functions in their respective
Parish/school jurisdictions.

iv) Board of Governors and School Management Committees, which oversee the work of head teachers. These are mainly parent and local community representatives.

v) Head teacher, teachers, support staff and students' prefects, who ensure a smooth day-today running of their schools.

With the exception of number (v), the rest of the above (i-iv) are included in what this study refers to as "Diocesan educational leadership". The study intentionally referred to these as (educational) "leadership", and not (educational) "management" [29], because of the wide, but often forgotten, influence these officials wield in steering the course of education in the Diocese - they should go ahead of everyone else ("lead") in showing the way forward.

This especially applies to the Education Secretary, the Parish Priests and Fathers-in-charge-of-Schools (or Chaplains), who, in a way, are the direct link between the Church and the school [30]. Yet also Boards of Governors/School management Committees are vested with important powers to offer critical assistance to school administrators $[24,30]$. They are supposed to monitor and evaluate the effectiveness of school administration, hence ensuring quality Catholic education.

As for the school administration (Head teacher, deputy/deputies, and teachers) they shoulder the following duties;

i) Duty to the vision and mission of the school;

ii) Duty to the school curriculum;

iii) Duty to the pastoral care of the learners and other members of staff within the school;

iv) Equitable distribution of school resources;

v) Acting as public relations managers of the school;

vi) Efficient administration of the school; and,

vii) Acting as the immediate eyes of Christ and the Bishop in the school.

Since a priest or head teacher cannot be readily available all the time, the Catholic Church attaches a lot of importance on the classroom teacher, who, in many instances stays with children for a long time [2]. The leaves an indelible mark on learners psychological, pedagogical, intellectual and spiritual growth and development.

It is also pertinent to note that in Uganda a cordial working relationship is still enjoyed between the Church and State in as far as partnering for education service delivery is concerned, exceptions notwithstanding. Religious Education still forms part of the official/national curriculum at all levels - whether Christian or Islamic Religious Education. How effectively does the Diocesan educational leadership utilise such an opportunity to enhance its denominational Catholic philosophy?

\section{Denominationalism in Greater Kampala Catholic Schools}

\subsection{Study Methodology}

The study's second objective was realised using a descriptive case study design $[31,32]$. The objective was 
to establish the role that the Diocesan educational leadership is actually playing in enhancing a Catholic denominational education philosophy.

Head teachers, fathers-in-charge-of-schools, school chaplains, students, members of the Board of governors (BOG), School Management Committees (SMC) members and parish priests were the study's primary respondents. These were sampled from 20 and 24 Catholic-founded primary and secondary schools (respectively) drawn from Greater Kampala District (currently subdivided into the four districts of Kampala, Mukono, Wakiso and Mpigi). The study utilised also the expertise of the Diocesan Education Secretariat and the Uganda Catholic Secretariat, but as secondary respondents. Their views indeed helped to give the study a more generalizable tone. Whereas interview, documentary review and observation were the data collection methods; data itself was analysed using thematic analysis and descriptive statistics.

Key issues of interest for the survey were;

i) Presence of a Catholic environment in the school as indicated for example by presence of crucifixes or images of saints in classrooms, or recorded regular visits by a priest;

ii) Empirical presence of the Diocesan educational leadership in schools in terms of direct and indirect supervision;

iii) Explicit indicators of provision of spiritual guidance to learners, teachers and other staff by the Chaplains, Fathers-in-charge or parish priests;

iv) The conduct of school management, administration and teachers as role models.

v) Implementation of Church/Diocesan education policies alongside State ones;

vi) Influence of the school to the local community, and vice versa, including affordability of school services to the local community.

\subsection{Study Findings}

The study first sought to establish if there was a "Catholic environment" in these Church founded schools. Catholic environment in this context entailed: Children attending Mass on a regular basis, reciting the holy rosary (especially during months of May and October), having at least some priest coming to school to offer services, encouraging prayer whenever students meet in a group, or singing Church hymns. The Catholic environment also implies the existence of statues of the Virgin Mary or St. Joseph, or a picture of the Pope or the Diocesan Bishop.

On a positive note, in many of the sampled schools, picture and religious articles (such as crucifixes and paintings of saints) were evident in both offices and classrooms. However, most of them were worn out.

Also $40(89 \%)$ of the 44 schools surveyed had vision/mission statements with a definitive Catholic dimension, such as "Everything for Christ's sake" and "To serve God and neighbour". However, only 20\% of head teachers could tell/recite the missions/visions of their schools! An even smaller percentage was conversant with the mission of denominational Catholic education in general. These findings make one doubt if these are the best agents to champion Catholic education.
On the issue of supervision, it was revealed by $69 \%$ of the respondents that there is lack of effective supervision by the Diocesan education leadership. This leaves head teachers to do whatever they feel suits their private interests and not the interest of the Roman Catholic Church. This view was echoed by such head teachers as one who observed that:

There is no meaningful supervision from the archdiocesan education secretariat. So long as the school pays the annual arch diocesan fee then no one will bother coming to the school to disturb you. You give them their money, and you [go ahead to] do your own things.

However, there were also some conscientious head teachers who still faithfully play their part, despite irregular supervision from the Diocesan educational leadership. For example one female head teacher noted that;

The Church made me what I am. It formed me into a unique character that I cherish dearly. So I do my services here with all due dedication, whether am supervised or not. I owe the Church, and I owe the nation this service.

One only wonders, what proportion of such personally dedicated and convinced school administrators still exists in Catholic schools. In any case, Diocesan educational leadership failure to closely supervise the different schools leaves a "value vacuum" which might easily be filled with secularism. Indeed in many Ugandan Church schools there seems to be a nascent trend towards secularism, permissiveness and relativism.

It was also revealed that most Chaplains or Fathers-incharge are not playing their part of providing pastoral counselling and guidance to head teachers, classroom teachers and students. As many as $82 \%$ of the interviewed teachers, and $73 \%$ of the head teachers revealed that most Chaplains appear to be ignorant of their true role in a Catholic school. For example, one head teacher said that;

Whenever I ask the chaplain to counsel students he refuses and requests me to look for professional counsellors. What then is he here for?

When some Chaplains were asked about this allegation they noted that it is true there are many challenges adolescents are facing today, most of which are too complicated for an ordinary Chaplain to handle. They cited challenges emanating from both the information technology and certain strange contemporary value stances as issues which do complicate their pastoral work in the school terrain.

On issues of conduct of BOGs and SMCs in assisting school administration to effect Diocesan educational policies, local community members mainly complained about a certain commercialisation of most Catholic elite schools. By "elite" they mean schools which are Roman Catholic founded but also receive funding from the Uganda government. These are schools which are usually only attended by children of well to do families (those with a higher socio-economic status background). On this issue, one priest lamented that:

It is true, missionaries established these schools to help the poor children in those areas in which the schools are located to also have some decent education. Unfortunately today many are not given any chance to 
access these schools because their parents are poor. But sons and daughters of the rich even if they are not Catholic are taken in simply because they have the money.

But some respondents contended that it does not matter anymore whether it is Catholic or non-Catholic learners that attend Church schools; what is more important is that some Ugandans are attending those schools to develop their country. One Religious Brother argued that;

Whether Catholic, atheist, Moslem or what, we are attended to by the same medical doctors in hospitals. So let any students attend our [Church] schools, excel, [and] come to serve us as doctors, engineers, lawyers, politicians. We are no longer in an era of parochial Catholicism.

What do such voices reflect about enhancement of Catholic denominational education philosophy, especially if they come from the Religious - the supposedly core Diocesan educational leaders?

Related to that is the revelation by $80 \%$ of the respondents that parents prefer Catholic schools not necessarily because of the Catholic values in them, but because of their excellent academic performance. For example one respondent revealed that:

My neighbour forged a baptism certificate, and also paid someone to coach his son on how to recite Catholic prayers so as to get admitted in this [Catholic] school which has good academic standards.

The above discoveries imply that, like some of those that run Catholic schools, some of those who access these schools are not bothered if the true Roman Education is gotten or not, so long as their children pass well in national examinations.

More interestingly, the study discovered that about $43 \%$ of the head teachers surveyed have/own personal private schools, and sometimes use Catholic school resources for their personal private schools, according to teachers and parents interviewed. Such information was also shared by some Diocesan education offices. One official corroborated the above information when he said:

It is true some head teachers own personal schools and they use our school resources in their schools but there is little we can do to stop this practice. Some of these individuals are personal friends of our bosses.

This implies that also the Diocesan educational leadership is sometimes limited in authority to discipline some "big" school heads, who may have personal connections to the Bishop, for example. Such practices go far in compromising the ability of the Catholic denominational philosophy in realising its original objectives.

Apart from such interferences "from within", there is also interference "from without" - from Government interference in the appointment of head teachers, especially in government-aided Catholic founded schools. It seems that some head teachers bribe Government officials to keep their positions in certain "fat"/elite Catholic schools in the country. Such interference compromises also the proper work of evangelization so espoused by these theistic schools, at least in principle.

Government also sometimes introduces programs that tend to run counter to Catholic doctrine and teaching, for example, secular sex education and introduction of neutral prayers in government-aided schools. These are indications of secularization of post-independence education in Uganda with an aim of waning the influence the Church had on education.

Indeed traditional Catholic associations (such as Region of Mary, Xaverians, and the Pioneer Movement) are to be found in just a handful of Catholic schools. Elsewhere they have been replaced with such secular associations as Youth Alive, Youth against HIV /AIDS, and Interact Group. Some of these may in the long run go against the core tenets of Catholic values, for example on the youth's access to condoms and premarital sex. On this issue, one Chaplain observed that:

It's a pity, though we all agree that these new and seemingly novel associations are good for the children's future, they are not Catholic. The young Catholics in these schools are now denied a chance to venture into Catholic traditional associations which used to build a truly Catholic character in the youth.

A different discovery was that Catholic communities (Catholic laity at the Parish level) are not consulted on what takes place in Catholic schools in their neighbourhood. One member of the Board of Governors observed that:

These head teachers plus the parish priest don't think the parishioners matter in as far as issues of our schools are concerned. Our children are not given a chance to study in these schools because we are poor and cannot afford the exorbitant fees in these schools. We end up taking our children to private schools, where Church services are rare.

Respondents further revealed that many school Boards of Governors/Management Committees are selected at the undue influence of the head teacher, and thus are compromised at their very inception: they cannot effectively supervise the head teachers under their jurisdiction. Also because sometimes Parish priests and Chaplains/Fathers-in-charge resort to head teachers financial assistance to run the Parish, their ability to supervise head teachers is grossly compromised. These findings imply that the Diocesan educational leadership chain is broken at several key points.

The findings also indicate that almost all Catholic schools have adopted commercial practices used by other schools to generate seemingly excellent academic performance. For example, many of these schools have two sets of candidates; namely, those who are deemed high achievers and the low achievers. While the "high achievers" are coached and registered in the school; "low achievers" are doomed as failures, and, consequently, are "sold" to private for-profit schools for registration (for national examinations).

There were also cases of Non-Catholic teachers handling (instructing) religious education in Catholic founded schools. In reaction to this, one chaplain complained that:

I have found it very intriguing that many of the teachers who teach religious education in our schools are not practicing Catholics. Some are even Anglicans or Pentecostals. They propagate heresies. Many of them do not even know what Catholic catechism is all about.

Teachers also complained that both they and their students are forced by head teachers to work (teach/learn) 
on Catholic days of obligation including; and, as such, students grow up familiarized with working on these days. During interview, one classroom teacher further revealed that:

Our head teacher said: we have to teach these children all the time since we are not in a monastery or a seminary. Students came here to study, not to loiter in the church or the school compound. Any teacher who refuses to teach on Sunday let him/her find another school elsewhere.

It was also obvious that it is largely only in schools headed by religious Nuns that students knew typically Catholic prayers such as the rosary. For the case of schools in which students were not encouraged to pray regularly, the study construed it as an indication of a drift from the Catholic philosophy of education.

Finally, review of ([24]: 95-112) showed that generally Diocesan education leaders had not adequately fulfilled their due responsiblities in Chruch founded schools. There is more concern for academic pursuits and financial profit than with learners' holistic growth and development as children created in God's image. So how effective is the Diocesan educational leadeship in enhancing a denominatioanl education philosphy?

\section{Reflections and Concluding Observations}

This study set out to examine the effectiveness of the Diocesan education leadership in enhancing a denominational educational philosophy in Uganda, taking the case of Catholic educational institutions in Greater Kampala. The study considered effectiveness both in theory (literature review); and in practice (using a survey). The study now concludes that whereas in principle the Roman Catholic Church in Uganda goes far in enhancing its denominational educational philosophy, its effectiveness in doing so in practice is highly compromised. Going by realities in many Catholic founded schools, there is too little of Catholic denominational education philosophy to show on the ground. Much of this is explained by the ineffectiveness of the Diocesan education leadership in doing its work - it is the mainly the Diocesan Secretariat, Parish priest, Father-in-charge/Chaplain and/or BOG/SMC that are to blame. They are hardly doing the work that is clearly documented in church documents for them to be doing.

There is therefore genuine cause for concern with regard to present day Catholic denominational education in Uganda. Without being alarmist, the current study argues that there is need to raise a question not only in terms of the survival of the Catholic philosophy of education but also the survival of the very Catholic Church itself. This is so because it is in these schools that the young, the future flock, the future shepherds within the Catholic Church, have to be nurtured so that in turn they are able to nurture others in future. If supervision of the young's nurturing goes wrong, then the Church's future gets in question. It is the Diocesan educational leadership that should jealously guard the education of the Church's young generation, if the Catholic denominational tradition is to stand.
This study therefore views the Diocesan education leadership's constrained supervisory presence as a key value constraining factor in enhancing denominational education in Uganda. Secondly, also the many cases of corruption in Uganda, abuse of office by civil servants, infidelity by both the laity and clergy appear to have a strong bearing on the nature of educational values accessed in the. If the Diocesan education leadership, and thus the Catholic school, play their intended true axiological and epistemological roles, the influence of Catholic schools, which are found in all parts of Uganda, will be more visible in society. Otherwise Uganda may never have sustainable peace and development of the whole person without the Church and other religious institutions taking a central stage in education [33,34].

Christian education enshrined in denominational schools are potentially the pillar on which Uganda stands to rebuild its war ravaged and disease infested country. As President Nyerere said, Christianity may become irrelevant if the Church does not distinguish itself from the sometimes bogus education offered by the secular world [25]. The Church may do this by acting strongly in promotion of its denominational education philosophy. Not mere speeches and writings will save denominational education philosophies in Uganda; the two will have to be supported by action, for example regular school supervision by the diocesan education leadership.

There is need for the different religious traditions to revive their denominational education philosophies in their schools; of course bearing in mind the many changed realities on the ground, such as respect for freedom of worship. On their part, Catholic schools should exemplify institutions clearly countering today's neo-nihilistic philosophy, which is far more protracted than what Arthur Schopenhauer (1788-1860) and Friedrich Nietzsche (1844-1900) alluded to; namely: the death of conventional reason, the death of God and the annihilation of conventional morality which all seem to be the order of the day - not only at the global level, but also here in Uganda despite more than a century of formal civilisation/education, both denominational and non-denominational.

Finally, this study is deemed limited by both its content and geographical scope (having focused only on the Roman Catholic denominational philosophy, moreover only in schools in Greater Kampala), as well as by its descriptive case study methodology. More research is therefore needed to extrapolate the study's results; preferably using survey methodology and inferential statistics.

\section{References}

[1] Mulligan, J. (1999). A Catholic Education: The future is now. Ottawa, ON: Canada Novalis.

[2] Genza, G. M. \& Muwagga, A. M. (2014). Human and economic development implications of selected knowledge-mediation practices prevalent among secondary school teachers in central Uganda. Journal of Development Studies (UMU, Nkozi) 1(4) (2014), pp. $69-88$.

[3] Kasibante, F. \& Kiwanuka, P. (ed.) (2001) Catholic Schools 2000 Issues and Challenges. Marianum Press Kisubi.

[4] Odawa, M. (2004). Quality Early Childhood and Primary Education in Uganda: A Case of Catholic Schools. In Kasibante I. F. (Ed.). A New Educational Agenda for Uganda. Kisubi: Marianum Publishing Company. 
[5] Businge, C. and Eremu, J. (2010). Top A' level School in Uganda. Saturday Vision February 6, 2010 Vol.4 No.06

[6] Kafuuma, J. (2005). Report on the state of Catholic schools in Kampala archdiocese. Kampala arch-diocese, Lubaga.

[7] Kasibante, I. F. (2004). Catholic School Mission and Character. Education Report 2004. The Archdiocese of Kampala.

[8] Kafuuma J (2005). Report on the state of Catholic schools in Kampala archdiocese. Kampala arch-diocese, Lubaga.

[9] Nsereko-Munakukaama, (1997). Secularization of Post Independence education in Uganda and its Significance for moral Education in Public Primary and Secondary Schools 1963-1985 Un published Doctoral Thesis. Makerere University Kampala.

[10] Muwagga, M. A., Genza, G. M. \& Ssemulya, R. (2013) School Leadership and Denominational Identity: The case of Roman Catholic-Founded Schools in Uganda: American Journal of Educational Research ,2013, vol.1, No.8, 327-333. http://pubs.sciepub.com/education/1/8/10

[11] Njoroge, R. \& Bennaars, G. A. (2000). Philosophy and Education in Africa: An Introductory Text for Students of Education. Nairobi: Transafrica Press.

[12] Muwagga, M. A. (2005). The Philosophical implications of Liberalization of University Education in Uganda. Unpublished doctoral thesis Makerere University Kampala Uganda

[13] Pontifical Council for Justice and Peace (2004). Compendium of the Social Doctrine of the Church. Pauline Publications Africa: Nairobi

[14] Borsi, M. (2002). Role and Objectives of the Catholic School in Mission. Roma: Pontifical Missionary Union.

[15] Congregation for Catholic Education (1998). The Catholic School on the Threshold of the Third Millennium. Rome: Author.

[16] Russell, B. (1996). History of Western Philosophy and its Connection with Political and Social Circumstances from the Earliest Times to the Present Day. London: Routledge

[17] Foley, M.A. \& Mohan, W.J. (1987). Philosophical inquiry: an introduction. New York: Society of St. Paul.

[18] Parankimalil, J. (2006), Catholic Catechism for All. Vincentian Retreat Centre Entebbe Uganda

[19] Flannery, A. (2003). Vatican Council II Post Councilor Documents. St Paul Publishers, Newdheli
[20] Ehrlich, T. (2006). The Impact of Higher Education on Moral and Civic Responsibility. July 22, 2006: http://www.collegevalues.org

[21] Grace, G. (2002). Catholic schools. London: Routledge Falmer

[22] Bryk, A. Lee V. \& Holland P. (1993). Catholic Schools and the Common Good. Cambridge U.P.

[23] Francis, P. (2015). Laudato Si Encyclical Letter of the Holy father Francis on Care for our Environment Paulines Publications Africa Nairobi.

[24] Kampala Arch-Diocese Synod Commison (2006). A Catholic's Mision in the archdiocese of Kampala. Marianum Press Kampala Kisubi.

[25] Agostoni, T., (2001). Every Citizens Handbook Building a Peaceful Society Nairobi, Pauline Publications.

[26] Odawa, M. (2004). Quality Early Childhood and Primary Education in Uganda: A Case of Catholic Schools. In Kasibante I. F. (Ed.). A New Educational Agenda for Uganda. Kisubi: Marianum Publishing Company.

[27] Agenzia Fides (2015). Catholic Church Statistics 2015. http://www.fides.org/en/news/58595-

VATICAN World Mission Day Catholic Church Statistics 20 15 12th January, 2018

[28] Ssekamwa, J. C. (2000). History and Development of Education in Uganda. Kampala: Fountain publishers.

[29] Rost, J. C. (1993). Leadership for the twenty-first Century, Praeger, London.

[30] Arch Diocese of Kampala Synod Commission (2006). A Catholic's Mission in the Archdiocese of Kampala , Marianum Press: Kisubi

[31] Kombo, K.D., \& Tromp, L.A.D. (2006). Proposal and thesis writing: an introduction. Nairobi: Pauline Publications Africa.

[32] Gay, L. R. (1996). Educational research: competencies for analysis and application (5th ed.). New Jersey: Prentice-Hall, Inc.

[33] Tangaza, W.J. (2009). The Acholi Justice System and the Conflict in Northern Uganda. The East African Journal of Humanities and Sciences, Volume 9 number 12009.

[34] Chummar. C.P (2008). In search of a Catholic identity for Higher education in AMECEA. The East African Journal of Humanities and sciences, Vol. 8 Number 2. 